\title{
Development of Healthy Snacks (Sev) Supplemented from Spirulina platensis Powder and Oragnelopetic Evaluation
}

\author{
Seema $^{1 *}$, S. Jood ${ }^{1}$ and Mahima Kumari ${ }^{2}$ \\ ${ }^{1}$ Department of Foods and Nutrition, CCS Haryana Agricultural University, \\ Hisar, Haryana, India \\ ${ }^{2}$ Department of Foods and Nutrition, B.P.S Mahila Vishwavidalya, Khanpur kalan, \\ Sonipat, Haryana, India \\ *Corresponding author
}

A B S T R A C T

\begin{tabular}{l} 
K e y w o r d s \\
$\begin{array}{l}\text { Proximate } \\
\text { composition, } \\
\text { Spirulina, } \\
\text { Organoleptic } \\
\text { evaluation }\end{array}$ \\
Article Info \\
$\begin{array}{l}\text { Accepted: } \\
18 \text { December } 2020 \\
\text { Available Online: } \\
\text { 10 January } 2021\end{array}$ \\
\hline
\end{tabular}

\section{Introduction}

Today, malnutrition is one of the severe crisis in world. As per Several statistical reports it affects not less than one in four children around the world. Indeed, it is a major killer of children every hour of every day. Chronic malnutrition is more lethal and more extensive than short term acute malnutrition (Bhan and Bahl, 2003). Both under and over nutrition posing threat of double burden of malnutrition. Thus urgent step is required to be taken towards the direction of providing proper balanced nutrition. Though, malnutrition can be easily cured with supportive nutrition balance and drug regimen. It is always better to fortify them with required nutritional contents to avoid future chances of malnutrition. So there is need of development of fortified food items.

Snacks are very popular today among all generations of human beings specially children and adolescent. These foods are generally refined, rich in fat, carbohydrates and energy, but lacking in dietary fibre and 
micronutrients (Udayasree et al., 2013; Padma and Rajendran, 2017). Therefore, nutritional enrichment of these food products can be advantageous to use as carrier of nutrients due to their simple manufacturing process, better shelf life, high acceptability and consumption (Fadaei et al., 2013; Hafsa et al., 2014).

Spirulina is well known blue-green algae with heavily loaded micronutrients required for human body. Spirulina is categorized as super food and recommended by WHO and NASA. For value addition, nutrient rich ingredients like Spirulina and chickpea flour can be used along with wheat flour for enhancing the nutritional quality of wheat based bakery and traditional recipes (Mohammed et al., 2012; Lohekar 2014; Samta \& Jood 2018; Rao 2018). Keeping this fact in view, the present study was planned with objectives to develope value added healthy snacks, and evaluation of their sensory properties and nutritional value.

\section{Materials and Methods}

The present study was carried out in the Department of Foods and Nutrition, I.C. College of Home Science, Choudhary Charan Singh Haryana agricultural university, Hisar, Haryana during the year 2017-2019.

\section{Procurement and preparation of samples}

Wheat and bengal gram flour were procured in a single lot from local market. Spirulina powder (food grade) was also procured from market. All the samples were stored in airtight plastic containers for further use.

\section{Standardization and formulation of composite flour}

Different proportions of wheat flour, bengal gram flour and Spirulina powder were used for formulation of composite flour. As a control, bengal gram flour $(100 \%)$ was used for Sev. Four types of composite flours were prepared by using wheat flour, bengal gram flour and Spirulina powder i.e in the ratios of 50:50:0 (control), 49:49:2 (Type-I), 48:48:4 (Type-II), 47:47:6 (Type-III) and 46:46:8 (Type-IV).

\section{Development of healthy snacks (Sev)}

Snacks were prepared by blending wheat flour, bengal gram flour and Spirulina platensis powder at different levels. Sev were prepared by blending wheat flour, bengal gram flour and Spirulina platensis powder at different levels.Ingredient with different levels are given in Table 1.

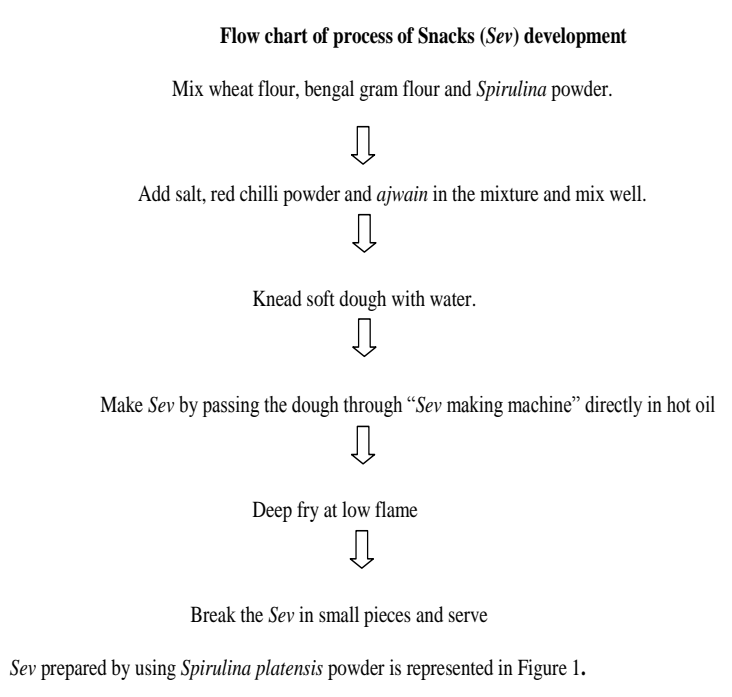

\section{Organoleptic acceptability of developed value added snacks (Sev)}

All the developed value added food products were organoleptically evaluated for their colour, texture, appearance, taste and overall acceptability by using 9-point Hedonic scale. On the basis of organoleptic acceptability, acceptable value added healthy snacks were further evaluated for their proximate composition. 


\section{Proximate composition}

The proximate composition of food products were determined by employing the standard methods of analysis AOAC, (2000). Crude protein was estimated by standard method of (AOAC 2000) using KEL PLUS Automatic Nitrogen Estimation System.

The micro Kjeldahl method was employed to determine the total nitrogen and the crude protein $(\mathrm{N} x$ 5.95). Crude fat was extracted using petroleum ether using the Automatic SOCS Plus Solvent Extraction System. The ash and crude fibre contents were determined based on methods outlined in AOAC, (2000).

\section{Statistical analysis}

The data obtained were analyzed statistically using standard methods of analysis (Sheoran \& Pannu 1999).

\section{Results and Discussion}

Organoleptic characteristics of developed value added food products

Mean scores of organoleptic characteristics (colour, appearance, aroma, texture, taste and overall acceptability) of developed value added snacks $(\mathrm{Sev})$ are presented in the Table 2. Overall acceptability scores of $\mathrm{Sev}$ made from wheat flour and four types of composite flour i.e. Type-I, Type-II, Type-III and TypeIV were 8.26, 7.72, 7.42, 6.74 and 5.62, respectively. It was observed that $\mathrm{Sev}$ made from Type-IV composite flour scored lowest overall acceptability scores. Acceptability of Sev was found to be decreased with increasing the level of incorporation of Spirulina powder in wheat-bengal gram flour blend. Similar results were also reported by the workers in Spirulina supplemented bread, biscuits and snacks (Navacchi et al., 2012; Minh 2014; Saharan 2017; Shinde et al., 2018).

Table.1 Proportion of different ingredients

\begin{tabular}{|c|c|c|c|c|c|c|}
\hline Supplementation level (\%) & Ghee (g) & $\begin{array}{c}\text { Ajwain } \\
\text { (g) }\end{array}$ & $\begin{array}{l}\text { Red chilli } \\
\text { powder }\end{array}$ & Salt & Oil & $\begin{array}{c}\text { Lukewarm } \\
\text { water }\end{array}$ \\
\hline Control $(100 \%$ BF $)$ & 10.0 & 2.5 & \multirow[b]{2}{*}{ To taste } & \multirow[b]{2}{*}{$\begin{array}{l}\text { To } \\
\text { taste }\end{array}$} & \multirow[b]{2}{*}{$\begin{array}{l}\text { For } \\
\text { frying }\end{array}$} & \multirow[b]{2}{*}{$\begin{array}{c}\text { For kneading } \\
\text { Dough }\end{array}$} \\
\hline $\begin{array}{l}\text { WF:BF:SP } \\
\text { 49:49:2 (Type-I) } \\
\text { 48:48:4 (Type-II) } \\
\text { 47:47:6 (Type-III) } \\
\text { 46:46:8 (Type-IV) }\end{array}$ & $\begin{array}{l}10.0 \\
10.0 \\
10.0 \\
40.0\end{array}$ & $\begin{array}{l}2.5 \\
2.5 \\
2.5 \\
2.5\end{array}$ & & & & \\
\hline
\end{tabular}

$\mathrm{WF}=$ Wheat flour $\mathrm{BF}=$ Bengal flour $\mathrm{SP}=$ Spirulina powder

Table.2 Mean scores of organoleptic characteristics of value added Sev

\begin{tabular}{|l|c|c|c|c|c|c|}
\hline Types of Sev & Colour & Appearance & Aroma & Texture & Taste & Overall Acceptability \\
\hline $\begin{array}{l}\text { Control } \\
\text { (BGF 100\%) }\end{array}$ & $8.40 \pm 0.48$ & $8.40 \pm 0.33$ & $8.10 \pm 0.26$ & $8.20 \pm 0.25$ & $8.20 \pm 0.30$ & $8.26 \pm 0.32$ \\
\hline Type-I & $7.70 \pm 0.17$ & $7.70 \pm 0.22$ & $7.70 \pm 0.23$ & $8.00 \pm 0.17$ & $7.50 \pm 0.31$ & $7.72 \pm 0.29$ \\
\hline Type-II & $7.50 \pm 0.11$ & $7.30 \pm 0.17$ & $7.30 \pm 0.20$ & $7.80 \pm 0.20$ & $7.20 \pm 0.27$ & $7.42 \pm 0.31$ \\
\hline Type-III & $7.10 \pm 0.17$ & $6.30 \pm 0.19$ & $6.30 \pm 0.31$ & $7.10 \pm 0.21$ & $6.90 \pm 0.16$ & $6.74 \pm 0.11$ \\
\hline Type-IV & $6.20 \pm 0.18$ & $5.70 \pm 0.40$ & $5.70 \pm 0.28$ & $6.00 \pm 0.20$ & $5.50 \pm 0.17$ & $5.62 \pm 0.15$ \\
\hline CD $(\mathbf{p = 0 . 0 5 )}$ & 0.15 & 0.12 & 0.22 & 0.16 & 0.15 & 0.05 \\
\hline
\end{tabular}

Values are mean \pm SE of ten panelists

Type-I: WF: BGF: SP (49:49:2) Type-II: WF: BGF: SP (48:48:4)

Type-III: WF: BGF: SP (47:47:6) Type-IV: WF: BGF: SP (46:46:8)

WF: Wheat flour BGF: Bengal gram flour SP: Spirulina powder 
Table.3 Proximate composition of value added $\operatorname{Sev}(\%$, on dry matter basis)

\begin{tabular}{|l|c|c|c|c|c|}
\hline Types of Sev & Moisture* & Crude protein & Crude fat & Crude fiber & Ash \\
\hline Control (BGF 100\%) & $2.38 \pm 0.39$ & $19.38 \pm 0.06$ & $30.20 \pm 0.66$ & $2.62 \pm 0.19$ & $2.62 \pm 0.21$ \\
\hline Type-I & $2.92 \pm 0.48$ & $16.54 \pm 0.14$ & $31.40 \pm 0.45$ & $2.82 \pm 0.18$ & $2.73 \pm 0.15$ \\
\hline Type-II & $3.60 \pm 0.51$ & $18.39 \pm 0.16$ & $32.70 \pm 0.79$ & $3.04 \pm 0.16$ & $2.92 \pm 0.19$ \\
\hline Type-III & $4.02 \pm 0.23$ & $20.52 \pm 0.15$ & $34.30 \pm 0.67$ & $3.98 \pm 0.18$ & $3.42 \pm 0.12$ \\
\hline CD $(\mathbf{p = 0 . 0 5 )}$ & 0.29 & 0.07 & 0.43 & 0.14 & 0.10 \\
\hline
\end{tabular}

*On wet matter basis Values are mean \pm SE of three independent determinations.

Type-I: WF: BGF: SP (49:49:2) Type-II: WF:BGF: SP (48:48:4) Type-III: WF: BGF: SP (47:47:6) WF:

Wheat flour BGF: Bengal gram flour SP: Spirulina powder

Fig.1 Spirulina platensis powder supplemented Sev

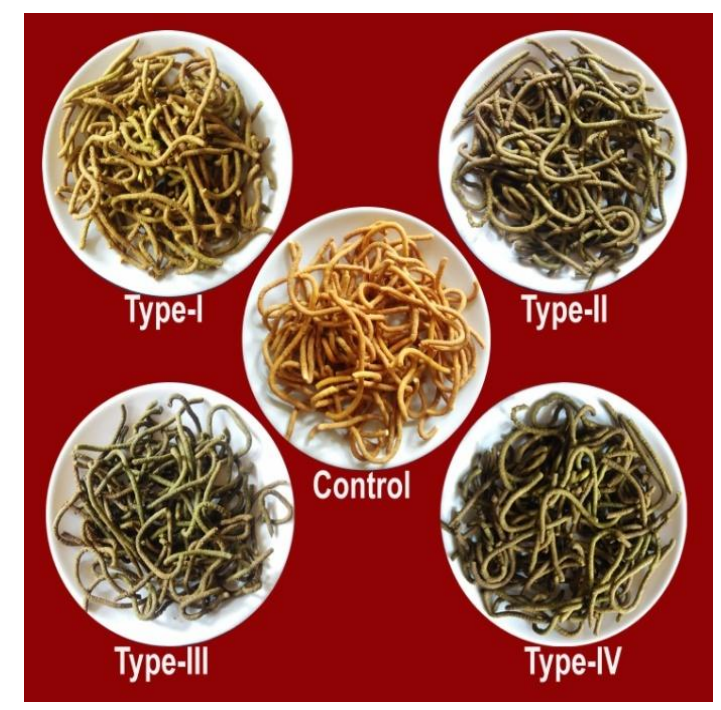

Control: Bengal gram flour (100\%)

Type-I: Wheat flour: Bengal gram flour: Spirulina powder (49:49:2)

Type-II: Wheat flour: Bengal gram flour: Spirulina powder (48:48:4)

Type-III: Wheat flour: Bengal gram flour: Spirulina powder (47:47:6)

Type-IV: Wheat flour: Bengal gram flour: Spirulina powder (46:46:8)

$\mathrm{WF}=$ Wheat flour $\mathrm{BF}=$ Bengal flour $\mathrm{SP}=$ Spirulina powder

Therefore, it can be concluded that, highly acceptable $S e v$ can be prepared using 6 per cent levels of Spirulina powder and addition of beyond 6 per cent levels of Spirulina powder significantly reduced the mean scores of colour, appearance, texture, taste and overall acceptability scores. Shinde et al., (2018) reported that Spirulina supplementation affected slightly sensory characteristics of supplemented products might be due to its green colour and appearance. Snacks up to $6 \%$ Spirulina had sensory acceptance.

\section{Proximate composition}

The proximate compositions of snacks have been summarized in Table 3. Bengal gram flour made served as control which exhibited 2.38 per cent moisture, 19.38 crude protein, 
30.20 per cent crude fat, 2.62 per cent crude fibre and 2.62 per cent ash contents which were found to be significantly improved with incorporation of Spirulina powder at 2, 4 and 6 per cent level. Type-III composite flour made $\mathrm{Sev}$ exhibited significantly higher content of moisture, crude protein, crude fat, crude fiber and ash followed by Type-II and Type-1 composite flour made Sev.

Similar results were reported in Spirulina supplemented biscuits, cookies and snacks by other workers (Sharma \& Dunkwal 2012; Vijyarani et al 2012; Ponciano 2015; Saharan 2017; Shinde et al., 2018)

Conclusively, this study has shown that healthy snacks can be developed using Spirulina powder supplementation along with bengal gram flour and wheat flour. Snacks up to $6 \%$ Spirulina manifested sensory acceptance. Consumption of Food products using such supplementation can go a long way in improving the nutritional status and health of the population especially for those suffering from Protein Energy Malnutrition.

\section{References}

AOAC., 2000. Official methods of Analysis, Association of Official Analytical Chemist. Washington, D.C.

Bhan, M. K., Bhandari, N., and Bahl, R. (2003). Management of the Severely malnourished child: perspective from developing countries. BMJ (Clinical research ed.), 326 (7381), 146-151. https://doi.org/10.1136/bmj.326.7381.1 46

Fadaei, V., Mohamadi, A. and Darani, K. (2013) Influence of Spirulina platensis powder on the starter culture viability in probiotic yoghurt containing spinach during cold storage. European Journal of Experimantal Biology, 3, 389-393.

Hafsa, Y.A., Amel, D., Samia, S. and
Sidahmed, S. (2014) Evaluation of nutritional and sensory properties of bread enriched with Spirulina. Annals Food Science and Technology, 15(2), 270-275.

Lohekar, A. S. and Arya, A.B. (2014) Development of value added Instant Dhokla Mix. International Journal of Food and Nutritional Science, 4(3), 7883.

Minh, N.P. (2014) Effect of Saccharomyces cerevisiae, Spirulina and preservative supplementation to sweet bread quality in bakery. International Journal of Multidisciplinary Research Development, 1(4), 36-44.

Mohammed, I., Ahmed, A.R., and Senge, B., (2012) Dough rheology and bread quality of wheat-chickpea flour blends. Industrial Crops and Products, 36, 196-202.

Navacchi, M.F.P., Carvalho, J.C.M., Takeuchi, K.P. and Danesi, E.D.G. (2012) Development of cassava cake enriched with its own bran and Spirulina platensis. Acta Scientiarum Technology, 34, 465-472.

Padma, A. and Rajendran, R. (2017) Development and evaluation of Spirulina incorporated little millet cookies. International Journal of Food and Fermentation Technology, 7(1), 119-122.

Ponciano, G.Y. (2015) Production and utilization of microalgae. International Journal of Current Research in Bioscience and Plant Biology, 2(5), 92100.

Rao (2018) Development and nutritional evaluation of micronutrient rich baked and traditional products. M.sc Thesis, CCS Haryana agricultural university, Hisar, India.

Saharan, V. and Jood, S. (2018) Dietary fibres, in vitro protein, total lysine, vitamin and antioxidant activity of 
noodles enriched with Spirulina platensis powder. Annals of Biology 34(1), 107-110.

Saharan, V. (2017) Value addition of food products using Spirulina plantesis: acceptability and nutrient composition. Ph.D Thesis, Dept. of Foods and Nutrition, CCS Haryana Agricultural University, Hisar, India.

Samta and Jood, S. (2018) Cooking Quality and acceptability of nutrient rich pasta developed from composite flour. International Journal of Current Microbiology and Applied Sciences, 7(04), 556.

Sharma, V. and Dunkwal, V. (2012) Development of Spirulina based "biscuits": a potential method of value addition. Journal of Ethnobiology and Ethnomedicine, 6(1), 31-34.

Sheoran, O.P. and Pannu, R.S. (1999) Statistical Package for agricultural workers. "O.P. Stat" College of Agriculture, Kaul, CCS Haryana Agricultural University, Hisar. India.

Shinde, Supriya and A. Lavale., Shivaji \& Nagare, Kiran. (2018) 'Spirulina' as an Additive for Better Nutrition. International Journal of Current Microbiology and Applied Sciences, 7, 143-147

Udayasree,V., Manjula, K. and Sowjanya, M. (2013) Effect of Spirulina as a nutritional supplement in malnourished children. International Journal of Scientific Research, 2, 2277-8179.

Vijayarani, D., Ponnalaghu, S. and Rajathivya, J. (2012) Development of value added extruded product using Spirulina. International Journal of Health Science and Research, 2(4), 4247.

\section{How to cite this article:}

Seema, S. Jood and Mahima Kumari. 2021. Development of Healthy Snacks (Sev) Supplemented from Spirulina platensis Powder and Oragnelopetic Evaluation. Int.J.Curr.Microbiol.App.Sci. 10(01): 2993-2998. doi: https://doi.org/10.20546/ijcmas.2021.1001.346 